\title{
Limitation of myocardial infarct size in patients less than 66 years treated with alprenolol
}

\author{
HANS J JÜRGENSEN, JENS FREDERIKSEN, DAN A HANSEN, \\ OLE PEDER SEN-BJER GAYARD
}

From Department of Medicine, Coronary Care Unit, Sundby Hospital, ${ }^{\star}$ Copenhagen, Denmark

SUMmaRY Two hundred and eighty-two patients less than 66 years of age admitted with suspected or definite myocardial infarction were allocated in a random fashion to treatment with alprenolol or placebo. Treatment was started immediately upon admission with 5-10 mg alprenolol or placebo intravenously, followed by $200 \mathrm{mg}$ alprenolol or placebo orally twice a day for one year. In 178 patients a definite myocardial infarction was diagnosed. Mycardial infarct size could be estimated from serial determinations of serum total creatine kinase in 42 patients treated with alprenolol and 43 patients receiving placebo. Median infarct size was $20.6 \mathrm{CK} \mathrm{g} \mathrm{Eq} / \mathrm{m}^{2}$ body surface in the alprenolol group, the corresponding figure in the placebo group being $34.4 \mathrm{CK} \mathrm{g} \mathrm{Eq} / \mathrm{m}^{2}$ body surface. Median rate of release of creatine kinase from the ischaemic myocardium was $27.7 \mathrm{U} / 1$ per hour and $48.0 \mathrm{U} / 1$ per hour after alprenolol and placebo, respectively. Alprenolol limited infarct size significantly provided the treatment was started within 12 hours of the onset of symptoms.

In patients admitted to hospital with an acute myocardial infarction extension of the ischaemic damage to the myocardium is often a dynamic process continuing for hours or days ${ }^{1-3}$ and is thus susceptible to treatment. Infarct size is related to the occurrence of arrhythmias ${ }^{45}$ and the development of pump failure ${ }^{16-8}$ during the clinical course and also carries prognostic weight ${ }^{5910}$; in animal studies it is related to the electrical stability of the myocardium-large infarcts lowering the threshold for ventricular fibrillation.11 Efforts intended to limit infarct size are therefore of major importance. A broad spectrum of measures favourably affects myocardial necrosis after coronary artery occlusion. ${ }^{12}$ The use of beta-adrenergic blocking drugs has received special attention in this connection and propranolol in particular has been extensively studied..$^{13-15}$

The aim of the present study was to investigate the effect of the beta-adrenergic blocking agent alprenolol on myocardial infarct size as estimated from serial determinations of serum creatine kinase (CK) in patients less than 66 years of age.

*Additional members of Sundby Hospital study group: Mogens Andersen, Peter Bechsgaard, Peder B. Nielsen, Flemming Pedersen, Søren L Rasmussen.

Received for publication 28 November 1980

\section{Patients and methods}

From 1 March 1976 until 31 December 1978 all patients admitted to the Coronary Care Unit, Sundby Hospital, Copenhagen, with a suspected or a definite acute myocardial infarct were considered for participation in a double-blind controlled trial of alprenolol. A detailed description of the study design and the mortality data has been given previously. ${ }^{16}$ There were 482 patients aged less than 66 years but

Table 1 Criteria for exclusion from trial

\begin{tabular}{|c|c|}
\hline Criteria & $\begin{array}{l}\text { No. of } \\
\text { patients }\end{array}$ \\
\hline $\begin{array}{l}\text { Cardiogenic shock } \\
\text { Pulmonary oedema persisting after } 2 \text { hours } \\
\text { AV block (Mobitz type } 2 \text { nd and } 3 \text { rd degree) } \\
\text { Bradycardia }<40 \text { beats/min } \\
\text { Chronic obstructive pulmonary disease } \\
\text { Labile diabetes mellitus } \\
\text { Death immediately after admission } \\
\text { Non-resident in area } \\
\text { Treatment with a beta-blocker on admission } \\
\text { Refusal to participate } \\
\text { Terminal or other disease } \\
\text { Other }\end{array}$ & $\begin{array}{r}16 \\
33 \\
9 \\
11 \\
25 \\
5 \\
8 \\
14 \\
61 \\
10 \\
6 \\
2\end{array}$ \\
\hline Total & 200 \\
\hline
\end{tabular}


200 were excluded from entry into the trial mainly because of contraindications to beta-blockade or because they were already receiving this treatment (Table 1). The remaining 282 patients were randomised-140 to treatment with alprenolol and 142 to placebo. Using WHO criteria ${ }^{17}$ a definite myocardial infarct was diagnosed in 178 patients. Infarct size as assessed by serial determinations of serum CK was estimated in 85 patients, 42 in the alprenolol group and 43 in the placebo group. The reasons why infarct size was not estimated in the remaining 93 patients are listed in Table 2 .

Table 2 Reasons why infarct size was not estimated

\begin{tabular}{lcc}
\hline Causes of exclusion & $\begin{array}{c}\text { Alprenolol } \\
\text { no. of patients }\end{array}$ & $\begin{array}{l}\text { Placebo } \\
\text { no. of patients }\end{array}$ \\
\hline Defibrillation & 13 & 17 \\
No increase of CK & 4 & 3 \\
Less than 10 CK values obtained & 10 & 10 \\
Maximum CK values on admission & 7 & 7 \\
Other reasons & 10 & 12 \\
\hline Total & 44 & 49 \\
\hline
\end{tabular}

After arrival in the Coronary Care Unit treatment was started as soon as possible with $5 \mathrm{mg}$ alprenolol or placebo intravenously. This dose was repeated after 10 minutes if the blood pressure or heart rate had not dropped by 10 per cent or more. Three hours later the patients received $200 \mathrm{mg}$ alprenolol or placebo orally and subsequently $200 \mathrm{mg}$ alprenolol/placebo orally twice a day for one year. A sustained release preparation (Aptin Durules) was used.

Blood samples for the analysis of serum total CK were obtained on admission and every four hours for the first two days. Thereafter, blood samples were drawn every morning for the rest of the first week and subsequently once weekly until the end of the study. Serum total CK was assayed as described by Rosalki. ${ }^{18}$ Patients received no intramuscular injections.

Infarct size (IS) was estimated from serial determinations of serum $\mathrm{CK}^{71920}$ using the formula

$$
\begin{gathered}
=\frac{B W \times D V}{P_{C K} \times\left(C K_{N}-C K_{I}\right)} \times E(t) \\
+k_{d} \int_{O}^{T} E(t) d t
\end{gathered}
$$

IS: $\quad$ is stated in $\mathrm{CK}$ gram equivalents $(\mathrm{CK} \mathrm{g}$ $\mathrm{Eq}), 1 \mathrm{CK} \mathrm{g} \mathrm{Eq}$ being the quantity of myocardium undergoing necrosis show- ing total $\mathrm{CK}$ depletion equivalent to the depletion in $1 \mathrm{~g}$ of tissue undergoing homogeneous necrosis in the centre of the infarct. ${ }^{19}$

BW: body weight (kg).

DV: distribution volume unit body weight ( $\mathrm{ml} / \mathrm{kg}$ ).

$\mathrm{P}_{\mathrm{CK}}$ : $\quad$ proportion of $\mathrm{CK}$ released into blood compared with $\mathrm{CK}$ depleted from the heart.

$\mathrm{CK}_{\mathrm{N}}$ : $\quad \mathrm{CK}$ activity in a homogeneous section of normal myocardium.

$\mathrm{CK}_{\mathrm{I}}$ : $\quad \mathrm{CK}$ activity in a homogeneous section of infarcted myocardium.

$k_{d}$ : fractional rate of disappearance of CK from blood per hour.

$E(t)$ activity of $C K$ in blood at the time ( $t)$ of the last observation $(\mathrm{U} / \mathrm{ml})$.

The following values were used in calculations ${ }^{21}$ : DV: $\quad 50 \mathrm{ml} / \mathrm{kg} ; \mathrm{P}_{\mathrm{C} \mathrm{K}} ; 0 \cdot 15$.

$\mathrm{CK}_{\mathrm{N}}$ : $\quad 1300 \mathrm{U} / \mathrm{g}$.

CK I: $\quad 195 \mathrm{U} / \mathrm{g}$.

T: $\quad 200$ hours.

Using a computer program ${ }^{22} \mathrm{CK}$ values were plotted in a serum curve as a function of time. An invasion curve depicting the integrated appearance of $\mathrm{CK}$ into the distribution volume as a function of time was also plotted. $k_{d}$ values were calculated from the descending part of the serum curve for each patient individually. ${ }^{7}$ Calculated $k_{d}$ values in the interval 0.03 to 0.09 per hour were used directly for estimating infarct size. Calculated $k_{d}$ values outside this interval were considered inaccurate. Accordingly, values $<0.03$ and $>0.09$ per hour were fixed at 0.03 and 0.09 per hour, respectively. In a few patients $k_{d}$ could not be calculated and in these cases $k_{d}$ was fixed at 0.06 per hour. ${ }^{9}$ The rate of appearance of $\mathrm{CK}$ from the ischaemic myocardium into the blood was defined as 90 per cent of the total $\mathrm{CK}$ appearance divided by the time taken to reach this percentage. ${ }^{15}$

For tests of significance the Mann-Whitney rank sum test for unpaired data was employed. Infarct size was plotted as a function of delay time assuming linear regression.

\section{Results}

Nineteen per cent of the patients treated with alprenolol (8/42) had previously suffered a myocardial infarct as compared with 14 per cent $(6 / 43)$ of those receiving placebo. Median infarct size in the alprenolol group was $20 \cdot 6 \mathrm{CK} \mathrm{g} \mathrm{Eq} \mathrm{per} \mathrm{m}^{2}$ body surface, the corresponding figure in the placebo 
group being $34.4 \mathrm{CK} \mathrm{g}$ Eq per $\mathrm{m}^{2}$ body surface ( $<<0.025$; Fig. 1). Appearance rate of CK from the ischaemic myocardium into the blood was $27.7 \mathrm{U} / 1$ per hour and $48.0 \mathrm{U} / 1$ per hour, respectively $(p<0.025$; Fig. 2$)$. The $k_{d}$ values in the two treatment groups were $0.45 \pm 0.002$ per hour and $0.39 \pm 0.002$ per hour (mean $\pm S E M$ ) (not significant).

Median delay from the onset of symptoms until treatment was 6.0 hours (interquartile range: $3.0-18.0$ ) in the alprenolol group and 5.0 hours (interquartile range: $3 \cdot 0-12.5$ ) in the placebo group (not significant). The relation between the delay and infarct size in the two treatment groups is displayed in Fig. 3. Provided that treatment was initiated within 12 hours from the start of symptoms a significant limitation of infarct size was obtained in patients receiving alprenolol. Beyond this time limit no significant difference was demonstrable.
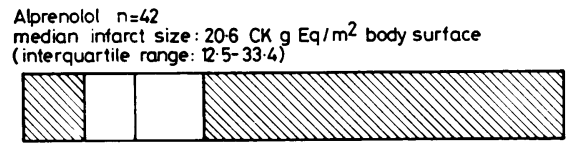

$$
p<0.025
$$

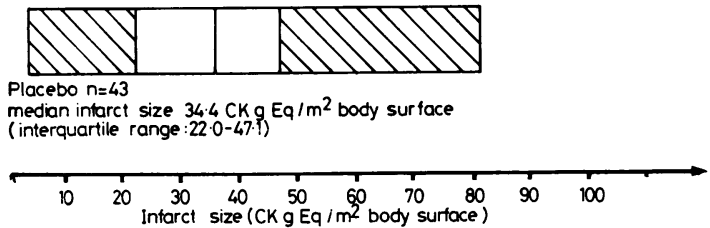

Fig. 1 Myocardial infarct size in patients less than 66 years of age treated with alprenolol or placebo. Infarct size related to body surface area is given along the $X$ axis. Total range, quartiles, and median values are also shown. White area : interquartile range.

\section{Discussion}

Alprenolol, a non-selective beta-adrenergic blocking agent possessing intrinsic sympathomimetic as well as membrane stabilising properties, has been shown in two prospective randomised controlled studies to reduce long-term mortality in patients suffering an acute myocardial infarction. ${ }^{16}{ }^{23}$ This study presents evidence that in patients who were less than 66 years, it also limits infarct size as estimated from serial determinations of serum CK.

Our patients were all less than 66 years of age. Older patients were studied but in the end there were insufficient numbers of comparable patients for meaningful analysis. The reasons for this were
Alprenolol $n=42$

median appearance rate $: 27.7 \mathrm{U} / \mathrm{l}$ per $\mathrm{h}$

(interquartile range: $18 \cdot 0 \cdot 45 \cdot 4$ )

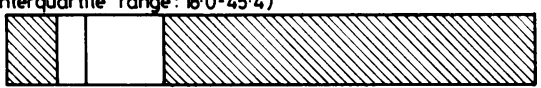

$p<0.025$

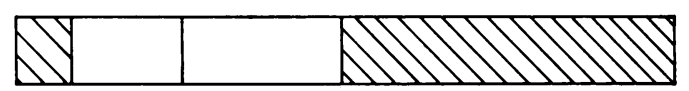

Placebo $n=43$

median appearance rate : $48.0 \mathrm{U} / \mathrm{l}$ per $\mathrm{h}$

(interquartile range: $18.4-92 \cdot 2$ )

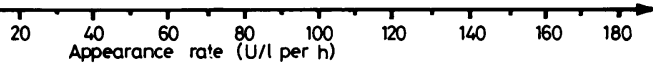

Fig. $2 C K$ appearance rate from ischaemic myocardium to the blood stream in patients less than 66 years of age treated with alprenolol or placebo. Enzyme appearance rate is given along the $X$ axis. Total range, quartiles, and median values are shown. White area: interquartile range.

that, compared with those in the placebo group, more of those treated with alprenolol had had a previous myocardial infarction, more were admitted quickly, and more died in the early days after infarction. ${ }^{16}$

Several different methods of estimating infarct size are available. ${ }^{1024-27}$ The method based upon serial determinations of serum $\mathrm{CK}$ was chosen because it is non-invasive and because it is currently used in our Coronary Care Unit. The method

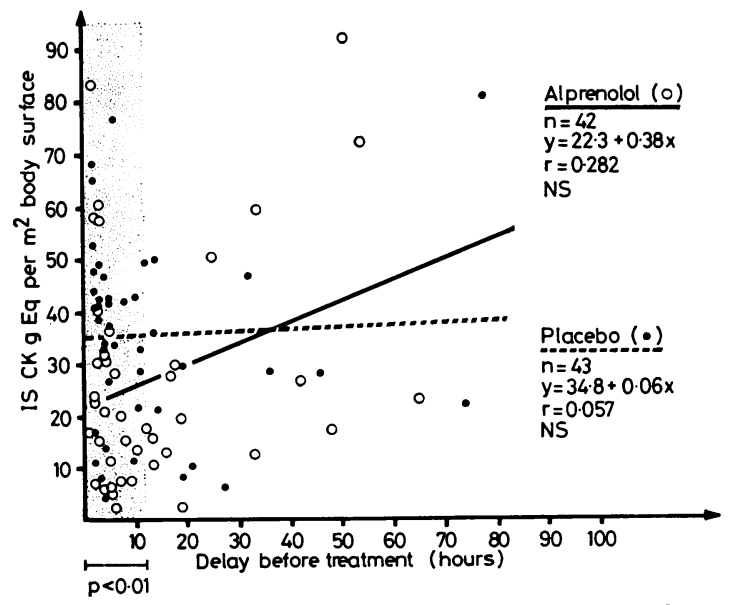

Fig. 3 Myocardial infarct size related to duration of symptoms before treatment in patients less than 66 years of age treated with alprenolol or placebo. Shaded area: observations in patients treated within 12 hours from onset of symptoms. 
is supported by extensive animal studies. ${ }^{19} 2829$ In these the accumulated CK appearing in the blood has been shown to be well correlated with CK depletion from the myocardium and with the extent of necrosis as estimated histologically after a coronary artery occlusion. ${ }^{28}$ Furthermore, it is well correlated with infarct size judged from epicardial electrocardiographic mapping. ${ }^{30}$ In man infarct size calculated from serial determinations of serum CK is closely related to the extension of infarction judged pathoanatomically $\mathrm{y}^{21}$ and also correlates well with the clinical course. ${ }^{2} 578$ The accuracy of the method, however, has been doubted. ${ }^{31}$ Crucial to this, of course, is that depletion of CK from the myocardium depicts cellular death-and on the other hand that necrosis is regularly followed by release of CK. It is crucial, too, that a change in $\mathrm{CK}$ appearance does not merely reflect drug-induced changes in myocardial blood flow $^{32}$ or other alprenolol effects unrelated to true infarct size. These questions need further elucidation. CK disappearance from blood as expressed by the $k_{d}$ value is not changed by haemodynamic fluctuations after coronary artery occlusion, ${ }^{20}$ nor was it influenced in this as in other studies ${ }^{15}$ by the betablocking agent.

In the present investigation it was possible to calculate infarct size in approximately 50 per cent of the patients having an established acute myocardial infarction. Basing the calculation of infarct size on serial determinations of the specific myocardial CK MB isoenzyme would have increased this percentage by not making it necessary to exclude patients who received direct current shock and those progressing to cardiogenic shock. Apart from this, estimates based upon the $\mathrm{CK} M B$ isoenzyme do not seem to be more accurate than those based upon total CK. ${ }^{20}{ }^{33}$

Our findings of the limiting effect of betaadrenergic blockade on infarct size are in good agreement with those published by others. ${ }^{13-153435}$

The limitation of the extent of necrosis is based upon an improved balance between myocardial oxygen supply and demand. The major determinants of oxygen consumption are heart rate, the contractile state of the myocardium, ventricular wall tension, and shortening of the contractile fibres against a load (Fenn effect). ${ }^{36}$ Heart rate and contractile state, mainly influenced by catecholamines, which are known to reach high levels in acute myocardial infarction ${ }^{37}$ and which do increase myocardial oxygen consumption, ${ }^{38}$ are reduced by beta-adrenergic blockade, ${ }^{39} 40$ but the net effect of this on ventricular wall tension is difficult to assess. Some workers have found that heart size increases after beta-blockade, ${ }^{41}$ thus tending to augment wall tension, while others have reported no increase in ventricular filling pressure. ${ }^{13} 3940$ Mean arterial blood pressure is somewhat reduced, ${ }^{13} 1439$ thus tending to decrease wall tension and oxygen consumption because of the Fenn effect.

There are other factors. Oxygen delivery is mainly related to coronary blood flow. The net effect of beta-adrenergic blockade is a reduction of total coronary blood flow. ${ }^{39} 4243$ Beta-blockers, however, seem to cause an advantageous redistribution of myocardial blood flow, increasing the ratio of endocardial to epicardial perfusion, ${ }^{43} 44$ but conclusions from studies performed in animals with normal coronary vessels should not be extended to human ischaemic heart disease. The oxygen affinity of haemoglobin may be reduced by propranolol, thus augmenting oxygen supply to the myocardial cells, ${ }^{45-47}$ but this finding has not been confirmed $^{48}$ and requires further study. Again, thrombocyte aggregation has been reported to be reduced by propranolol, ${ }^{4950}$ which might tend to improve the microcirculation in the ischaemic myocardium. The improved balance between oxygen supply and demand accomplished by the beta-adrenergic blockade causes a narrowing of the myocardial arteriovenous oxygen difference ${ }^{39}$ and, reflecting the improvement of the metabolic state, the ischaemic myocardial cells shift from lactate production to lactate extraction. ${ }^{39}$

We wish to express our gratitude to diplommathematiker P Mayiopoulos, Rechenzentrum der RWTH, Aachen, West Germany, who carried out the infarct size calculations.

\section{References}

1 Alonso DR, Scheidt S, Post M, Killip T. Pathophysiology of cardiogenic shock. Quantification of myocardial necrosis, clinical, pathologic and electrocardiographic correlations. Circulation 1973; 48: 588-96.

2 Mathey D, Bleifeld W, Buss H, Hanrath P. Creatine kinase release in acute myocardial infarction: correlation with clinical, electrocardiographic, and pathological findings. Br Heart $\mathcal{f}$ 1975; 37: 1161-8.

3 Inoue M, Hori M, Fukui S, et al. Evaluation of evolution of myocardial infarction by serial determinations of serum creatine kinase activity. $\mathrm{Br}$ Heart f 1977; 39: 485-92.

4 Roberts R, Husain A, Ambos HD, Oliver GC, Cox JR Jr, Sobel BE. Relation between infarct size and ventricular arrhythmia. $B r$ Heart $\mathcal{f} 1975 ; 37$ : 1169-75.

5 Geltman EM, Ehsani AA, Campbell MK, Schechtman $K$, Roberts $R$, Sobel BE. The influence of location and extent of myocardial infarction and 
long-term ventricular dysrhythmia and mortality. Circulation 1979; 60: 805-14.

6 Mathey D, Bleifeld W, Hanrath P, Effert S. Attempt to quantitate relation between cardiac function and infarct size in acute myocardial infarction. Br Heart $\mathcal{f}$ 1974; 36: 271-9.

7 Norris RM, Whitlock RML, Barratt-Boyes C, Small CW. Clinical measurement of myocardial infarct size. Modification of a method for the estimation of total creatine phosphokinase release after myocardial infarction. Circulation 1975; 51: 614-20.

8 Kahn JC, Guerret P, Menier R, Giraudet P, Ben Farhat M, Bourdarias JP. Prognostic value of enzymatic (CPK) estimation of infarct size. $\mathcal{F ~} \mathrm{Mol}$ Med 1977; 2: 223-31.

9 Sobel BE, Bresnahan GF, Shell WE, Yoder RD. Estimation of infarct size in man and its relation to prognosis. Circulation 1972; 46: 640-8.

10 Holman BL, Chisholm RJ, Braunwald E. The prognostic implications of acute myocardial infarct sintigraphy with ${ }^{99} \mathrm{~m}$ Tc-Pyrophosphate. Circulation $1978 ; 57$ : 320-6.

11 Bloor CM, Ehsani A, White FC, Sobel BE. Ventricular fibrillation threshold in acute myocardial infarction and its relation to myocardial infarct size. Cardiovasc Res 1975; 9: 468-72.

12 Maroko PR, Maclean D, Ribeiro LGT, Braunwald E. Pharmacological limitation of infarct size: enzymatic, electrocardiographic, and morphological studies in the experimental animal and man. In: Hearse DJ, de Leiris J, eds. Enzymes in cardiology, diagnosis and research. New York: John Wiley, 1979: 529-59.

13 Gold HK, Leinbach RC, Maroko PR. Propranololinduced reduction of signs of ischemic injury during acute myocardial infarction. Am $\mathcal{F}$ Cardiol 1976; 38: 689-95.

14 Norris RM, Clarke ED, Sammel NL, Smith WM, Williams B. Protective effect of propranolol in threatened myocardial infarction. Lancet 1978; ii: 907-9.

15 Peter T, Norris RM, Clarke ED, et al. Reduction of enzyme levels by propranolol after acute myocardial infarction. Circulation 1978; 57: 1091-5.

16 Andersen MP, Bechsgaard P, Frederiksen J, et al. Effect of alprenolol on mortality among patients with definite or suspected acute myocardial infarction. Lancet 1979; ii: 865-8.

17 World Health Organization. Ischemic heart disease registers; report of the fifth working group, Copenhagen: WHO Regional Office for Europe, 1971.

18 Rosalki SB. An improved procedure for serum creatine phosphokinase determination. f Lab Clin Med 1967; 69: 696-705.

19 Shell WE, Lavelle JF, Covell JW, Sobel BE. Early estimation of myocardial damage in conscious dogs and patients with evolving acute myocardial infarction. F Clin Invest 1973; 52: 2579-90.

20 Roberts R, Henry PD, Sobel BE. An improved basis for enzymatic estimation of infarct size. Circulation 1975; 52: 743-54.

21 Bleifeld W, Mathey D, Hanrath P, Buss H, Effert S.
Infarct size estimated from serial serum creatine phosphokinase in relation to left ventricular hemodynamics. Circulation 1977; 55: 303-11.

22 Mayiopoulos $P$, Mathey D, Hanrath $P$, Bleifeld W. Computer program for the evaluation of the infarct size from CK serial determination. Comput Biomed Res (to be published).

23 Wilhelmsson C, Vedin JA, Wilhelmsen L, Tibblin $G$, Werkö L. Reduction of sudden deaths after myocardial infarction by treatment with alprenolol. Lancet 1974: ii: 1157-60.

24 Maroko PR, Libby P, Covell JW, Sobel BE, Ross J Jr, Braunwald E. Precordial S-T segment elevation mapping: an atraumatic method for assessing alterations in the extent of myocardial ischemic injury. The effects of pharmacologic hemodynamic interventions. Am $\mathcal{f}$ Cardiol 1972; 29: 223-30.

25 Rogers WJ, McDaniel HG, Smith LR, Mantle JA, Russell RO Jr, Rackley CE. Correlation of angiographic estimates of myocardial infarct size and accumulated release of creatine kinase $\mathrm{MB}$ isoenzyme in man. Circulation 1977; 56: 199-205.

26 Sobel BE, Weiss ES, Welch MJ, Siegel BA, TerPogossian MM. Detection of remote myocardial infarction in patients with positron emission transaxial tomography and intravenous ${ }^{11} \mathrm{C}$-palmitate. Circulation 1977; 55: 853-7.

27 Wickline SA, McNamara JJ. Vectorcardiographic quantification of infarct size in baboons. Circulation 1978; 57: 910-20.

28 Kjekshus JK, Sobel BE. Depressed myocardial creatine phosphokinase activity following experimental myocardial infarction in rabbit. Circ Res 1970; 27: 403-14.

29 Shell WE, Kjekshus JK, Sobel BE. Quantitative assessment of the extent of myocardial infarction in the conscious dog by means of analysis of serial changes in serum creatine phosphokinase activity. f Clin Invest 1971; 50: 2614-25.

30 Maroko PR, Kjekshus JK, Sobel BE, et al. Factors influencing infarct size following experimental coronary artery occlusions. Circulation 1971; 43: 67-82.

31 Roe CR, Cobb FR, Starmer CF. The relationship between enzymatic and histologic estimates of the extent of myocardial infarction in conscious dogs with permanent coronary occlusion. Circulation 1977 ; 55: 438-49.

32 Roe CR, Cobb FR, Starmer CF. Peripheral enzyme appearance rates following acute myocardial infarction (MI): an index of perfusion of infarcted regions (abstract). Circulation 1975; 51 \& 52, suppl II: II-5.

33 Kupper W, Bleifeld W, Hanrath P, Effert S. Berechnung der akuten Infarktgrösse aus den Serumkonzentrationen des CK-MB-Isoenzymes. Dtsch Med Wochenschr 1978; 103: 550-6.

34 Pelides LJ, Reid DS, Thomas M, Shillingford JP. Inhibition by beta-blockade of the ST-segment elevation after acute myocardial infarction in man. Cardiovasc Res 1972; 6: 295-301.

35 Yusuf S, Ramsdale D, Peto $R$, et al. Early intra- 
venous atenolol treatment in suspected acute myocardial infarction. Lancet 1980: ii: 273-6.

36 Braunwald E. The determinants of myocardial oxygen consumption. Physiologist 1969; 12: 65-93.

37 Christensen NJ, Videbaek J. Plasma catecholamines and carbohydrate metabolism in patients with acute myocardial infarction. $f$ Clin Invest 1974; 54: 278-86.

38 Waldenström AP, Hjalmarson ÅC, Thornell L. A possible role of noradrenaline in the development of myocardial infarction. An experimental study in the isolated rat heart. Am Heart f 1978; 95: 43-51.

39 Mueller HS, Ayres SM, Religa A, Evans RG. Propranolol in the treatment of acute myocardial infarction. Effect on myocardial oxygenation and hemodynamics. Circulation 1974; 49: 1078-87.

40 Wirtzfeld A, Klein G, Delius W, Sack D. Behandlung des akuten Myokardinfarktes mit Metoprolol. Dtsch Med Wochenschr 1978; 103: 566-74.

41 Alderman EL, Coltart DJ, Robison SC, Harrison DC. Effects of propranolol on left ventricular function and diastolic compliance in man (abstract). Circulation 1973; 47 \& 48, suppl IV: IV-87.

42 Stein PD, Brooks HL, Matson JL, Hyland JW. Effect of beta-adrenergic blockade on coronary blood flow. Cardiovasc Res 1968; 2: 63-7.

43 Gross GJ, Winbury MM. Beta-adrenergic blockade on intramyocardial distribution of coronary blood flow. F Pharmacol Exp Ther 1973; 187: 451-64.

44 Becker LC, Fortuin NJ, Pitt B. Effect of ischemia and anti-anginal drugs on the distribution of radioactive microspheres in the canine left ventricle. Circ Res 1971; 28: 263-9.
45 Oski FA, Miller LD, Delivoria-Papadopoulos $M$, Manchester JH, Shelburne JC. Oxygen affinity in red cells: changes induced in vivo by. propranolol. Science 1972; 175: 1372-3.

46 Pendleton RG, Newman DJ, Sherman SS, Brann EG, Maya WE. Effect of propranolol upon the hemoglobin-oxygen dissociation curve. $f$ Pharmacol Exp Ther 1972; 180: 647-56.

47 Schrumpf JD, Sheps DS, Wolfson S, Aronson AL, Cohen LS. Altered hemoglobin-oxygen affinity with long-term propranolol therapy in patients with coronary artery disease. Am $\mathcal{f}$ Cardiol 1977; 40: 76-82.

48 Lichtman MA, Cohen J, Murphy MS, Kearney EA, Whitbeck AA. Effect of propranolol on oxygen binding to hemoglobin in vitro and in vivo. Circulation 1974; 49: 881-6.

49 Frishman WH, Christodoulou J, Weksler B, Smithen C, Killip T, Scheidt S. Abrupt propranolol withdrawal in angina pectoris: effects on platelet aggregation and exercise tolerance. Am Heart $\mathcal{f}$ 1978; 95: 169-79.

50 Mehta J, Mehta P, Pepine CJ. Platelet aggregation in aortic and coronary venous blood in patients with and without coronary disease. 3. Role of tachycardia stress and propranolol. Circulation 1978; 58: 881-6.

Requests for reprints to Dr Hans J Jürgensen, Department of Medicine, Sundby Hospital, DK2300 Copenhagen S, Denmark. 